\title{
The Effect of Audit Committee Characteristics on the Profitability: Panel Data Evidence
}

\author{
Yazan Oroud $^{1}$ \\ ${ }^{1}$ Faculty of Business, Isra University, Amman, Jordan \\ Correspondence: Yazan Oroud, Accounting Department, Faculty of Business, Isra University, Amman, Jordan. \\ E-mail: Oroud.yazan@iu.edu.jo
}

Received: January 24, 2019

Accepted: February 20, 2019

Online Published: March 28, 2019

doi:10.5539/ijef.v11n4p104

URL: https://doi.org/10.5539/ijef.v11n4p104

\begin{abstract}
This study attempts to investigat the relationship between audit committee characteristics (size, independence, meeting and financial expertise) and the profitability of industrial companies listed on the Amman Stock Exchange (ASE) for the years 2013 to 2017. The model of this study is theoretically founded on both the agency theory and the resource dependence theory. To examine the developed model, the data were gathered from the annual reports of 51 listed industrial firms. To analyse the data, this study utilized the panel data methodology on 51companies with 255 observations. Moreover, this study used company size and leverage as control variables. Based on the panel data results, the fixed-effect model was used to examine the effect of the experimental variables on profitability, measured by return on investment (ROI) and return on equity (ROE). The results show that the audit committee characteristics have a significant effect on profitability of the industrial companies listed on the ASE. This study evinces that the RD theory is more significant compared to the agency theory when describing CG practices in Jordan.
\end{abstract}

Keywords: audit committee, profitability, panel data, agency theory, resource dependence theory

\section{Introduction}

Business companies around the world need to develop and grow continuously by acquiring new investments, but potential investors often need to ensure that the business environment is stable and safe and that they can generate long-term profits (Al-Manaseer, Hindawi, \& Al-Dahiyat, 2012). With the collapse of many companies and the emergence of financial crises followed this led to a decline in confidence in institutions and companies added to the legislative bodies and through cuts and studies to explain the collapse of many major companies and the occurrence of financial crises show that the access of these companies On short-term debt as well as the interrelationships through friends and relatives and trying to hide these practices through different accounting methods and innovative and manipulating the financial statements of companies is also one of the main causes of these disasters and hence the great interest and increasing in the concept of corporate governance to provide it protects Investors by ensuring sound management practices (Bahren \& Strom, 2010; Mokhtar et al., 2009).

Audit committee is one of the main elements of the corporate governance helping to control management practices (Afify, 2009). In addition, audit committees help to improve the quality of financial reports and reduce audit risk (Contessotto \& Moroney, 2014) The audit committees play an important role in supervising and monitoring the management of the company in order to protect the interests of the owners (Kallamu \& Saat, 2015). It is recognized that the effectiveness of an audit committee can be gauged from the the company's performance and its competitiveness, especially in the changing business environment, which is outside the control of the company (Herdjiono \& Sari, 2017).

In response to the financial crises, the Jordanian government established regulations for the establishment of an audit committee in 2008 as part of a series of accounting reforms to improve corporate governance practices and restore investor confidence in companies listed on the Amman Stock Exchange (ASE). The government's recommendation to establish an audit committee was on a voluntary basis for companies, but in 2013, it was made mandatory for all companies listed on the ASE (Oroud et al., 2017; Alqatamin, 2018).

In recent years, the study of corporate governance, including the Audit Committee, has increased in the light of the collapse of several major financial institutions worldwide, such as, Arthur Andersen in 2001, Commercial 
Bank in 1991, Enron in 2001 and Fannie Mae in 2008 (Jackling \& Johl, 2009; Obiyo \& Lenee, 2011; Ii, Kankpang, \& Okonkwo, 2012; Makhlouf et al., 2017).

Jordan was exposed to the financial crisis during the years of 2007-2009, during which time, many companies were and are still affected by this crisis (ASE Report, 2009). This led to the loss of credibility and confidence of many investors in these companies (Masoud \& Aldas, 2014).

In this regard, the present study, using a sample of industrial companies listed on the ASE, attempts to determine the most important characteristics of the audit committee and their effect on the profitability of these companies, which in turn, aims to answer the main question of this study as follows:

- What is the relationship between the audit committee characteristics (the size of the committee, the independence of the committee, the meetings of the committee, the financial expertise of the members of the committee) and the profitability of Jordanian industrial companies listed on the Amman stock exchange (ASE)?

\section{Literature Review}

Over the past 15 years, there have been many attempts to understand the nature of corporate governance mechanisms and the ways in which these mechanisms affect the performance of companies (Pratheepkantha, Hettihewab, \& Wrightc, 2016) Researchers have generally measured the effectiveness of corporate governance through ownership and the structure of the board of directors; or through corporate governance provisions; or the characteristics of the Internal Audit Committee (Bucktowar et al., 2017). According to the Organization for Economic Cooperation and Development (2015), institutional governance is an essential element for the success of the organization. Donovan (2003) identified corporate governance as an internal mechanism that includes processes, policies and people who work for the owners of the enterprise by harmonizing sound management practices in terms of integrity and business knowledge that will ultimately lead to a sound board structure, thus creating an appropriate structure within the company.

The audit committee is a good corporate governance mechanism because it includes the quality, credibility, objectivity and integrity of the company's financial report. The audit committee has become an important mechanism in corporate governance, where the board has delegated many important functions, such as supervision of corporate governance and financial report to its standing committees (Zhang et al., 2007), specifically, the audit committee (Dhaliwal et al., 2010). As all members of the audit committee have oversight responsibility of the company's financial reporting process, their characteristics can enhance the effectiveness of the audit committee. Previous studies have concluded that an effective audit committee and its relevance to the quality of the company's financial reporting can reduce the management of earnings (Bedard et al., 2004); financial fraud (Sharma, 2004); and qualified audit reports (Carcello \& Neal, 2000).

As for the review of previous studies related to the audit committee, it is divided into two categories. The first part deals with the structure of the audit committee; while the second examines the relationship between the characteristics of the audit committee and their effects on company performance (Kamarudin, 2013).

It is important to note that the characteristics of the audit committee are an essential part of governance, as a guarantee that the management is accountable to the shareholders and presents a true and fair image of the company. The role of the audit committee is central to discussions between policymakers, supporters, investors and academics, which include holding regular meetings with external and internal auditors to identify any irregularities in financial reports, assessing risks and evaluating the company's internal control system. This reduces the gap between managers and shareholders by preventing monopoly over information in the administration and ensuring all reports are presented in a timely manner (Heenehgala \& Armtrong, 2011).

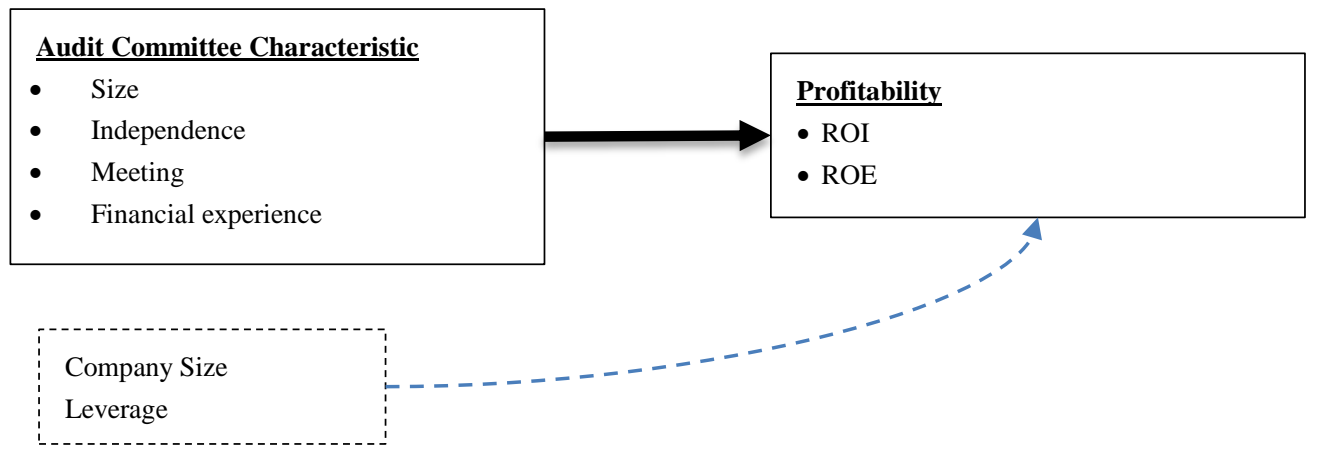


$\mathrm{H}_{1}$ : Audit committee characteristics have a significant effect on Profitability (ROI) of industrial companies listed on the ASE.

$\mathrm{H}_{2}$ : Audit committee characteristics have a significant effect on Profitability (ROE) of industrial companies listed on the ASE.

The regression analysis result is an equation appearing the most accurate prediction of the dependent variable based on the independent variable.

Model 1

ROI $_{i t}=\alpha+\beta_{1}$ size $_{i t}+\beta_{2}$ indp $_{i t}+\beta_{3}$ meet $_{i t}+\beta_{4} \exp _{i t}+\beta_{5}$ leverage $_{i t}+\beta_{6}$ cosize $_{i t}+e_{i t}$

Model 2

$\operatorname{ROE}_{i t}=\alpha+\beta_{1}$ size $_{i t}+\beta_{2}$ indp $_{i t}+\beta_{3}$ meet $_{i t}+\beta_{4}$ exp $_{i t}+\beta_{5}$ leverage $_{i t}+\beta_{6}$ cosize $_{i t}+e_{i t}$

where

ROI: Return on investment of company $i$ in year $t$.

ROE: Return on equity of company $i$ in year $t$.

$\alpha$ : Intercept.

$\boldsymbol{\beta}$ : Slope.

size $_{i t}$ : Audit committee size of company $i$ in year $t$.

ind $p_{i t}$ : Audit committee independence of company $i$ in year $t$.

meet $_{i t}$ : Audit committee meeting of company $i$ in year $t$.

$\boldsymbol{e x p}_{i t}$ : Audit committee financial experience of company $i$ in year $t$.

leverage $_{i:}$ Leverage of company $i$ in year $t$.

cosize $_{i t}$ : Company size (total assets) of company $i$ in year $t$.

$i$ : Company.

$\boldsymbol{t}$ : Current financial year.

$\varepsilon$ : Model's error of estimate.

\section{Research Methodology}

The study population consists of 63 industrial companies listed on the ASE as at the end of 2017. The focus is on the industrial companies listed on the ASE because they constitute the largest and most diversified sector. The industrial sector in Jordan is one of the main sectors in the Jordanian economy. It is also worth mentioning that the industrial sector plays an important and vital role in trading in the ASE. The study sample includes 51 companies out of 63 companies that met the following conditions: The company should be listed in the market and issued financial reports without interruption during the period of 2013-2017 and, the company was not merged or liquidated during the study period.

The parameters of the descriptive statistics (mean, standard deviation, minimum value and maximum value) were calculated for each of the variables of the combined main study according to companies and years. These variables are ROI, ROE, SIZE, INDP, MEET, EXP, COSIZE and LEVERAGE, as shown in Table 1.

Table 1. Descriptive analysis

\begin{tabular}{lllll}
\hline Variables & Mean & St. Deviation & Min & Max \\
\hline ROI & 0.342 & 9.749 & $46.271-$ & 38.396 \\
ROE & 1.221 & 20.473 & $78.936-$ & 145.483 \\
SIZE & 3.980 & 0.843 & 3 & 6 \\
INDP & 0.403 & 0.295 & 0 & 0.80 \\
MEET & 3.494 & 10.203 & 1 & 6 \\
EXP & 0.584 & 0.493 & 0 & 1 \\
COSIZE & 9.75 & 2.89 & 394795 & 1.80 \\
LEV & 34.945 & 23.811 & 0.400 & 19.473 \\
\hline
\end{tabular}

$\mathrm{ROI}=$ Return on investement $; \mathrm{ROE}=\mathrm{Return}$ on equity, $\mathrm{SIZE}=\mathrm{AC}$ size; $\mathrm{INDP}=\mathrm{AC}$ independence; $\mathrm{MEET}=\mathrm{AC}$ meeting, $\mathrm{EXP}=\mathrm{AC}$ financial experience, $\mathrm{COsize}=$ company size, $\mathrm{LEV}=$ leverage. 
Correlation analysis is important to describe trends and strengths in the linear relationship between variables (Pallaant, 2011). In the current study, linear correlation was checked to determine the strengths of relationships between the variables of the study as shown in Table 2 .

Table 1. Correlation analysis

\begin{tabular}{|c|c|c|c|c|c|c|c|c|}
\hline & ROI & ROE & Size & Indp & Meet & Exp & Cosi & Lev \\
\hline ROI & 1.000 & & & & & & & \\
\hline ROE & 0.529 & 1.000 & & & & & & \\
\hline Size & 0.127 & $0.027-$ & 1.000 & & & & & \\
\hline Indp & 0.029 & 0.053 & 0.062 & 1.000 & & & & \\
\hline Meet & 0.006 & $0.054-$ & 0.061 & 0.026 & 1.000 & & & \\
\hline Exp & 0.133 & 0.105 & 0.150 & 0.057 & 0.075 & 1.000 & & \\
\hline Cosi & 0.121 & 0.139 & $0.105-$ & 0.237 & $0.030-$ & 0.104 & 1.000 & \\
\hline Lev & $0.322-$ & 0.021 & $0.013-$ & 0.251 & $0.055-$ & $0.031-$ & 0.169 & 1.000 \\
\hline
\end{tabular}

ROI $=$ Return on investement $;$ ROE $=$ Return on equity, SIZE $=$ AC size; INDP = AC independence; MEET = AC meeting, EXP= AC financial experience, COsize = company size, $\mathrm{LEV}=$ leverage.

Hair et al. (2010) reported that the correlation coefficient 0 indicates that there is no relationship between the variables; while the correlation coefficient of \pm 1 indicates an ideal relationship between the variables. On the other hand, Sohn (1988) interpreted correlation coefficient values between 0 and \pm 1 as follows: from $\pm 10 \%$ to \pm $29 \%$, the relationship is weak; $\pm 30 \%$ to $\pm 49 \%$ means a clear and explicit relationship; and the highest value of $\pm 50 \%$ is strong relationship. Generally, the result of the study shows that all the links are less than $80 \%$. This is consistent with Gujarti and Porter (2009), where the correlation matrix should not exceed $80 \%$ to ensure that there are no problems of self-association

The problem of the extreme values (biased) is within the second category because it is considered one of the causes of the problems of heterogeneity of small samples (Heteroscedasticity) and can identify the extreme values or observations in the sample, which are too small or excessive in value (Gujarati, 2014). If found in the sample one of these methods is the Mahalanobis test. The current study followed the majority of suggestions that support the use of the Mahalanobis test.

Table 2. Mahalanobis distances and the residuals statistics

\begin{tabular}{|c|c|c|c|c|c|}
\hline & Minimum & Maximum & Mean & Std. Deviation & $\mathrm{N}$ \\
\hline Predicted Value & -14.27 & 12.54 & 0.320 & 3.971 & 255 \\
\hline Std. Predicted Value & -3.673 & 3.079 & 0.000 & 1.000 & 255 \\
\hline Standard Error of Predicted & .9220 & 3.562 & 1.443 & .3870 & 255 \\
\hline Adjusted Predicted Value & -13.69 & 12.14 & 0.330 & 3.961 & 255 \\
\hline Residual & -48.819 & 32.197 & 0.000 & 8.909 & 255 \\
\hline Std. Residual & -5.414 & 3.571 & 0.000 & .9880 & 255 \\
\hline Stud. Residual & -5.478 & 3.639 & -0.001 & 1.004 & 255 \\
\hline Deleted Residual & -49.970 & 33.437 & -0.010 & 9.192 & 255 \\
\hline Stud. Deleted Residual & -5.831 & 3.733 & -0.004 & 1.021 & 255 \\
\hline Mahal. Distance & 1.661 & 38.640 & 5.976 & 4.688 & 255 \\
\hline Cook's Distance & 0.000 & .1600 & .0050 & .0140 & 255 \\
\hline Centered Leverage Value & .0070 & .1520 & .0240 & .0180 & 255 \\
\hline
\end{tabular}

In this study, the researchers identified 11 extreme values as being considered safe because they constitute a small percentage of the total 255 observations. These observations can be deleted or maintained if the number is significant and constitutes a large proportion of the study sample (Pallant, 2013).

The use of fixed effect models or random effect as well as methods of treatment and improvement of these models may be affected in the event of removal or modification of extreme views. Therefore, in this study, biased views will be kept so as not to exclude the loss of views which may be important for conducting this study.

When there is a linear relationship between consecutive variables and independent variables which is highly 
correlated, the multiple linear problem emerges, the regression results become unclear and the results of the independent variables become unreliable (Gujarti, 2004). In previous studies, two statistical methods have been used to solve such problems. The main center methodology, the standard approach and each method determines the goal of the publication without affecting the regression results. In this study, the main center method was applied to reduce the correlation between independent variables.

Since panel and time-series data regression models may suffer from correlation problems or heterogeneity (Gujarti, 2004; Bultagi, 2008), this study used the modified Wald test, where the results show a problem of heteroskedasticity as shown in Table 5 .

Table 3. The modified Wald test for groupwise heteroscedasticity

\begin{tabular}{lll}
\hline Models & Chi-sq value & P value \\
\hline ROI & $1.7 \mathrm{e}^{5}$ & ${ }^{* * *} 0.000$ \\
ROE & $2.3 \mathrm{e}^{5}$ & ${ }^{* * *} 0.000$ \\
\hline
\end{tabular}

Note. Significant Level $* * *: * *=\mathrm{P}-$ Value $<1 \%, 5 \%$.

The current study used a new test known as the Wooldridge test to detect the autocorrelation in panel. This test is more efficient than other tests in this field and the most superior ones (such as Durbin-Watson). The Wooldridge test uses the first derivative residues of regression models and the results of the test in Table 6 reveal that the models developed by this study are devoid of autocorrelation problems of the first degree

Table 4. Outcomes of the Wooldridge test for autocorrelation

\begin{tabular}{lll}
\hline Model & F value & P value \\
\hline ROI & 33.563 & ${ }^{* * *} 0.000$ \\
ROE & 3.948 & 0.0524 \\
\hline
\end{tabular}

Note. Significant Level $* * *: * *=\mathrm{P}-$ Value $<1 \%, 5 \%$.

\section{Results}

The results include the effect of audit committee characteristic and profitability (ROI). Table 6 shows the results of the robust, fixed-effect (According to results of Breusch-Pagan L.M tests \& Hausman) using the regression correction with the Driscoll-Kraay standard errors method. The results point that the model fits the data at the 0.01 level of significance. moreover, in this model the predictors explain $115 \%$ of the variations in the ROI of the industries listed companies $\left(R^{2}=0.15\right)$. The constant term in this model is significant $(\alpha<0.01)$ and positive.

Table 5. Results of regression modelling- The first model

\begin{tabular}{|c|c|c|c|}
\hline \multicolumn{4}{|c|}{ ROI $_{\text {it }}=\alpha+\beta_{1} \operatorname{size}_{\mathrm{it}}+\beta_{2} \operatorname{indp}_{\mathrm{it}}+\beta_{3}$ meet $_{\mathrm{it}}+\beta_{4} \exp _{\mathrm{it}}+\beta_{5} \operatorname{lev}_{\mathrm{it}}+\beta_{6} \operatorname{cosize}_{\mathrm{it}}+\mathrm{e}_{\mathrm{it}}$} \\
\hline Variables & Coefficients & (t-static) & $\mathrm{P}$ \\
\hline Size & -0.014 & -0.04 & 0.970 \\
\hline Indp & 0.662 & 7.52 & $0.000^{* * *}$ \\
\hline Meet & 0.134 & 9.12 & $0.000^{* * *}$ \\
\hline Exp & -0.614 & -0.34 & 0.734 \\
\hline Lev & -0.029 & -0.11 & 0.914 \\
\hline Cosize & 0.023 & 6.82 & $0.000^{* * *}$ \\
\hline -cons & 33.153 & 12.67 & $0.000^{* * *}$ \\
\hline$R$-sq overall & $15 \%$ & & \\
\hline (F-value $)$ & $11.73^{* * *}$ & & \\
\hline
\end{tabular}

The results of the hypothesis test indicate that there is no significant relationship between the size of the audit committee and ROI and the value of $\mathrm{T}$ is -0.04 , which is less than the $\mathrm{T}$ tabulated; hence the hypothesis that there is a relationship between the size of the audit committee and profitability measured by ROI (where the value of $\mathrm{P}>0.10)$ is rejected. 
The results indicate that there is a significantly positive relationship between the independence of the audit committee and profitability (ROI); the value of $\mathrm{T}=7.52$ shows the possibility of a relationship between the independence of the audit committee and profitability (ROI) where the value of $\mathrm{P}<0.01$.

The results also show the test of hypothesis indicate that there is a significantly positive relationship between the number of meetings of the audit committee and profitability (ROI); the value of $\mathrm{T}=9.12$, showing the possibility of the existence of a relationship between the meetings of the Audit Committee and profitability (ROI) where the value of $\mathrm{P}<0.01$.

The results of the hypothesis test indicate that there is no significant relationship between the expertise of the audit committee and profitability as measured by ROI. The calculated $T$ value of -0.11 so we reject the hypothesis about the relationship between financial expertise of the Audit Committee and profitability (ROI) where the value of $\mathrm{P}$ more than $10 \%$.

Table 6. The results of regression modeling-The second model

\begin{tabular}{llll}
\hline ROE $_{\mathrm{it}}=\alpha+\beta_{1}$ size $_{\mathrm{it}}+\beta_{2}$ indp $_{\mathrm{it}}+\beta_{3}$ meet $_{\mathrm{it}}+\beta_{4} \exp _{\mathrm{it}}+\beta_{5} \operatorname{lev}_{\mathrm{it}}+\beta_{6} \operatorname{cosize}_{\mathrm{it}}+\mathrm{e}_{\mathrm{it}}$ & & \\
\hline Variables & Coefficients & (t-static $)$ & $\mathrm{P}>\mathrm{Z}$ \\
\hline Size & 1.71 & 2.79 & $0.007^{* * * *}$ \\
Indp & 0.15 & 1.79 & $0.079^{*}$ \\
Meet & 16.97 & 2.72 & $0.009^{* * *}$ \\
Exp & 2.14 & 1.15 & 0.257 \\
Cosize & 0.232 & 1.86 & $0.069^{*}$ \\
Lev & -0.01 & -1.66 & $0.10^{*}$ \\
-cons & -130.94 & -3.00 & $0.004^{* * *}$ \\
\hline$R$-sq overall & $16.80 \%$ & & \\
$($ F-value $)$ & $10.19^{* * *}$ & & \\
\hline
\end{tabular}

$*, * *, * * *=\mathrm{p}$-value $<.10, .05, .01 ; \mathrm{ROI}=$ Return on investement $; \mathrm{SIZE}=\mathrm{AC}$ size $; \mathrm{INDP}=\mathrm{AC}$ independence; MEET $=\mathrm{AC}$ meeting, $\mathrm{EXP}=$ $\mathrm{AC}$ financial experience, $\mathrm{COsize}=$ company size, lev $=$ leverage, $\varepsilon=$ error term.

The results include the effect of audit committee characteristic and profitability (ROE). Table 7 shows the results of the robust, fixed-effect (According to results of Breusch-Pagan L.M tests \& Hausman) using the regression correction with the Driscoll-Kraay standard errors method. The results point that the model fits the data at the 0.01 level of significance. moreover, in this model the predictors explain $16.79 \%$ of the variations in the ROE of the industries listed companies $(\mathrm{R} 2=0.1679)$. The constant term in this model is significant $(\alpha<.01)$ and negative.

There is no significant relationship between the size of the audit committee and ROI and the value of $\mathrm{T}$ is -0.04 , which is less than the $\mathrm{T}$ tabulated; hence the hypothesis that there is a relationship between the size of the audit committee and profitability measured by ROE (where the value of $\mathrm{P}>0.10$ ) is rejected.

The results indicate that there is a significantly positive relationship between the independence of the audit committee and profitability (ROI); the value of $\mathrm{T}=7.52$ shows the possibility of a relationship between the independence of the audit committee and profitability (ROE) where the value of $\mathrm{P}<0.01$.

The results also show the test of hypothesis indicate that there is a significantly positive relationship between the number of meetings of the audit committee and profitability (ROE); the value of $\mathrm{T}=9.12$, showing the possibility of the existence of a relationship between the meetings of the audit committee and profitability (ROE) where the value of $\mathrm{P}<0.01$.

The results of the hypothesis test indicate that there is no significant relationship between the expertise of the audit committee and profitability as measured by ROI. The calculated $\mathrm{T}$ value of -0.11 so we reject the hypothesis about the relationship between financial expertise of the audit committee and profitability (ROE) where the value of $\mathrm{P}$ more than $10 \%$.

\section{Discussion}

The study aims to discuss the emerging issues in the conflict of interest between shareholders and management within the corporate governance structure and the impact on the quality of performance of the Jordanian industrial companies. The characteristics of the audit committee are one of the tools of the corporate governance system. It is important to note that the size, independence and expertise of the members of the Committee may be beneficial for the companies in terms of management accountability and responsibilities towards the 
shareholders by ensuring that managers provide a true and fair view of companies and that irregularities are avoided. It is expected that the characteristics of the audit committee will give a good perception of the performance of the company

Based on the agency theory and the resource dependence theory, this study assumes that the size of the audit committee is expected to enhance profitability as the Audit Committee's main function is to assist in the supervision of the Board of Directors in an attempt to increase financial disclosure. Moreover, the Internal Audit Committee is one of the main elements of the corporate governance system, which plays a key role in monitoring the effectiveness of the internal control framework and supervising the financial reporting process of companies. It also acts as an intermediary between internal auditors, external auditors and the board of directors to develop an appropriate flow of information. The audit committee helps to ensure transparency in reporting.

Based on the statistical results of the current study, there is no correlation between the size of the audit committee and the profitability as shown in Tables 6 and 7. This finding is consistent with previous studies conducted in developing countries and China (Wei, 2007; Abdurrof, 2011). However, this result is not consistent with previous studies that have found a negative relationship between the size of the Audit Committee and Profitability of developed countries (Bozec, 2005). Moreover, this result is not consistent with some previous studies (Ghabayen, 2012) which have found a positive relation between the size of the Audit Committee and profitability in developed countries (Reddy et al., 2010; Bauer et al., 2009) and in developing countries (Al-Matari et al., 2012). One of the possible reasons for this result is that the audit committees in Jordan, especially the industrial companies are not important compared to other countries. Most companies have a minimum number of $\mathrm{AC}$ members.

According to the agency theory and the resource dependence theory, the independence of the Audit Committee plays a key role in ensuring the control of financial reports that leads to improved performance of the company. This study assumes a positive relationship between independence of the audit committee and profitability. Based on the statistical results, the study finds a positive relationship. Tables 6 and 7 show $\mathrm{H}_{1 \mathrm{~b}}$ and $\mathrm{H}_{2 \mathrm{~b}}$ are accepted. This result is supported by the Sarbanes-Oxley Act (2002), the Cadbury Commission in the UK and the Jordanian Corporate Governance Guidelines.

This study is in line with previous studies that have reported a positive relationship between the independence of the Audit Committee and profitability in developed and developing countries (Dey, 2008; Abdullah et al., 2008; Swamy, 2011). The reasoning behind this conclusion is that the independence of the Audit Committee is an important element of the committee in order to enhance the value of the company. The members of the committee have the ability to make the right decisions and achieve the established objectives of the committee independently of the management.

From the perspective of the agency theory and the resource dependence theory, repeated meetings of the Audit Committee may improve accounting processes and thus improve profitability. The study concludes that there is a relationship between the meetings of the Audit Committee and profitability. The result, as shown in Tables 6 and 7 , is that there is an important relationship between them and thus the hypothesis is accepted. This result is supported by the reorganization and the guidance of the Cadbury Commission 1992 and the BRC1999 in the United States. The rules of corporate governance for companies listed on the ASE are issued by the Securities Commission, which stipulates that the number of meetings of the Committee shall not be less than four times per year. These meetings are considered as important to solve the problems that the company may face during the operational cycle, thus improving the profitability. This study is not consistent with previous studies (Almotere et al., 2002; Colemam, 2007; Noor, 2011), which have found no correlation between the number of meetings and profitability.

According to the agency and the resource dependence theories, the financial expertise of the members of the Audit Committee plays a key role in ensuring the control of the financial reports, thus leading to enhanced company performance. This study assumed a positive relationship between the financial expertise of the members of the Audit Committee and profitability. Based on the statistical results, the relationship between financial expertise of the members of the Audit Committee in industrial companies and the profitability. This result is not consistent with the resource dependence theory that the expertise of managers, especially non-executives, has the ability to increase resources and thus positively affect profitability. The justification that can be inferred from this result is that the rules of corporate governance of Jordanian companies do not necessarily impose the necessity that the members of the committee possess only accounting or financial expertise. The text is to float the knowledge through a phrase or related that may involve many disciplines that may Do not touch the financial or accounting side 


\section{Recommendations and Conclusion}

In the light of the above, we recommend the following: first, the need to set a minimum for the number of Audit Committee members of industrial companies, so as to ensure the decisions of the Committee are efficient and effective in the decision-making processes; second, take into account the accounting and financial expertise among the members of the audit committees so that members can perform their duties professionally and effectively; third, update the Jordanian Corporate Governance Code to impose on companies, in general, and industrial companies, in particular, to fully disclose the number of members, meetings, independence, qualifications and practical experience in the annual report of the company; fourth, researchers should introduce variables that have not been studied together and their impact on financial and non-profitability; and finally, expand the application of the study to all listed companies on the ASE in order to reach a comprehensive model commensurate with the reality of Jordanian companies.

This study aims to identify the characteristics of the audit committee and its impact on the profitability of industrial companies listed on the ASE during the period of 2013-2017. In view of the theoretical and practical analysis of the investigations, firstly, the independence of the Audit Committee is influenced by the characteristics of the Committee on the profitability of the rest of the return on investment and the return on owners' equity; secondly, the impact of the meetings of the Audit Committee during the year on the profitability measured by return on investment in addition to the return on the owners' equity; thirdly, there is no statistical significance between the number of members of the Audit Committee or the financial expertise of members and profitability; fourthly, the size of the industrial company has an impact on the relationship between the characteristics of the Internal Audit Committee and profitability ; and finally, there is no statistical impact on the relationship between financial leverage of industrial companies and the characteristics of the Audit Committee and profitability.

To sum up, in general, there is an impact on the characteristics of the audit committees of the industrial companies on the ASE on profitability measured by ROI and ROE.

\section{References}

Abdullah, M. S., Shah, S. Z. A., \& Hassan, A. (2008). Impact of corporate governance on financial performance of firms: Evidence from Pakistan. Business Review, 11(2), 282-289.

Abdurrouf, M. A. (201 1). The relationship between corporate governance and value of the firm in developing countries: Evidence from Bangladesh. The International Journal ofApplied Economics and Finance, 5(3), 237-244.

Afify, H. (2009). Determinants of audit report lag: Does implementing corporate governance have any impact? Empirical evidence from Egypt. Journal of Applied Accounting Research, 10(1), 56-86. https://doi.org/10.1108/09675420910963397

Aldamen, H., Duncan, K., Kelly, S., McNamara, R., \& Nagel, S. (2012). Audit committee characteristics and firm performance during the global financial crisis. Accounting \& Finance, 52(4), 971-1000. https://doi.org/10.1111/j.1467-629X.2011.00447.x

Al-Matari, Y. A., Al-Swidi, A. K., \& Faudziah, H. B. F. (2012). Audit committee effectiveness and performance of Saudi Arabia listed companies. Wulfenia Journal, 19(8), 169-188.

Alqatamin, R. M. (2018). Audit Committee Effectiveness and Company Performance: Evidence from Jordan. Accounting and Finance Research, 7(2), 48. https://doi.org/10.5430/afr.v7n2p48

Andrew, R. G., \& Carol, M. (2000). Audit Committee Cadbury Code and Audit Fees: An Empirical Analysis of UK Companies. Managerial Auditing Journal, 15(7), 358-371. https://doi.org/10.1108/02686900010344638

Arens, A. A, Elder, R. J., \& Mark, S. B. (2010). Auditing and Assurance Services: An ntegrated Approach (10th ed.).

Baez, A. (2014). A panel data analysis of FDI and informal labor markets. Research Institute of Applied Economics, (4), 1.

Bahren, O., \& Stram, R. O. (2010). Governance and politics: Regulating independence and diversity in the board room. Journal of Business Finance \& Accounting, 37(9), 1308-1281. https://doi.org/10.1111/j.1468-5957.2010.02222.x

Baltagi, B. H. (2008). Econometric analysis of panel data (4th ed.). John Wiley \& Sons, Ltd.

Bauer, R., Eichholtz, P., \& Kok, N. (2009). Real estate, corporate governance and performance: The Reit Effect. 
Financial Management, 1-29.

Berle, A., \& Means, G. (1932). The modern corporation and private property. New York: Macmillan.

Bradbury, J. (2006). Territory and power revisited: Theorising territorial politics in the United Kingdom after devolution. Political Studies, 54(3), 559-582. https://doi.org/10.1111/j.1467-9248.2006.00615.x

Bucktowar, R., Kocak, A., \& Padachi, K. (2015). Entrepreneurial orientation, market orientation and networking: Impact on innovation and firm performance. Journal of Developmental Entrepreneurship, 20(4). https://doi.org/10.1142/S1084946715500247

Collier, P. A. (1993). Audit Committees in Major UK Companies. Managerial Auditing Journal, 8(3), 25-30.

Contessotto, C., \& Moroney, R. (2014). The association between audit committee effectiveness and audit risk. Accounting \& Finance, 54(2), 393-418. https://doi.org/10.1111/acfi.12010

Dey, A. (2008). Corporate governance and agency conflicts. Journal of Accounting Research, 46(5), 1143-1181. https://doi.org/10.1111/j.1475-679X.2008.00301.x

Dezoort, F. T., Hermanson, D. R., Archambeault, D. S., \& Reed, S. A. (2002). Audit Committee Effectiveness: A Synthesis of EmpiricalCommittee Literature. Journal of Accounting Literature, 21, 38-75.

Easton, P. D. (2004). PE ratios, PEG ratios, and estimating the implied expected rate of return on equity capital. The Accounting Review, 79(1), 73-95. https://doi.org/10.2308/accr.2004.79.1.73

Eisenhardt, K. M. (1989). Agency theory: An assessment and review. Academy of Management Review, 14(I), 57-74. https://doi.org/10.5465/amr.1989.4279003

Fama, E., \& Jensen, M. (1983). Agency problems and residual claims. The Journul of Law and Economics, 26(2), 327-349. https://doi.org/10.1086/467038

Ghabayen, M. (2012). Board characteristics and finn perfonnance: Case of Saudi Arabia. International Jolrrnal ofAccounting and Financial Reporting, 2(2), 168-200. https://doi.org/10.5296/ijafr.v2i2.2145

Greene, E. M. (2008). Internal HR Consulting: Why doesn't your staff get it?

Gujarati, D. N., \& Porter, D. C. (2009). Basic Econometrics (5th ed.). New York McGraw-Hill.

Hair, J. F., Anderson, R. E., Tatham, R. L., \& Black, W. C. (2010). Multivariate data analysis (2nd ed.). New York: Prentice-Hall, Upper Saddle River, NJ.

Hair, J., Black, B., Babin, B., Anderson, R., \& Tatham, R. (2006). Multivariate data analysis (6th ed.). Upper Saddle River, NJ: Prentice-Hall.

Haniffa, R., \& Hudaib, M. (2006). Corporate governance structure and performance of Malaysian listed companies. Journal of Business Finance \& Accounting, 33(7\&8), 1034-1062. https://doi.org/10.1111/j.1468-5957.2006.00594.x

Herdjiono, I., \& Sari, I. M. (2017). The Effect of Corporate Governance on the Performance of a Company. Some Empirical Findings from Indonesia. Journal of Management and Business Administration, 25(1), 33-52. https://doi.org/10.7206/jmba.ce.2450-7814.188

Hillman, A. J., Cannella, A. A. Jr., \& Paetzold, R. L. (2000). The resource dependence role of corporate directors: Strategic adaptation of board composition in response to environmental change. Journal of Management Studies, 37, 235-255. https://doi.org/10.1111/1467-6486.00179

Hoyos, R. E. D., \& Sarafidis, V. (2006). Testing for cross-sectional dependence in paneldata models. TIze Stata Journal, 6(4), 482-496. https://doi.org/10.1177/1536867X0600600403

Jackling, B., \& Johl, S. (2009). Board structure and firm performance: Evidence from India's top companies. Corporrite Governance: An Internationril Review, 17(4).

Jensen, M., \& Meckling, W. H. (1976). Theory of the firm: Managerial behavior, agency costs, and ownership structure. Journal of Financial Econonzics, 3, 305-360. https://doi.org/10.1016/0304-405X(76)90026-X

Joe, D., Kankpang, K., \& Okonkwo, G. (2012). Corporate governance as a driver of organizational efficiency in courier service firms: Empirical findings from Nigeria. Interdisciplinary Journal of Research in Business, $1(11), 26-38$.

Kallamu, B. S., \& N. A. M. Saat. (2015). Audit committee attributes and firm performance: Evidence from Malaysian finance companies. Asian Review of Accounting, 23(3), 206-231 https://doi.org/10.1108/ARA-11-2013-0076 
Kevin, L. J. (2000). The Effects of Internal Audit Outsourcing on Financial Statement Users' Cofidence in their Protection from Fraudulent Financial Reporting. Retrieved from http://library.tamu.edu/

Makhlouf, M. H., Laili, N. H., Ramli, N. A., \& Basah, M. Y. (2017). Board of directors' effectiveness and firm performance: Evidence from Jordan. Research Journal of Finance and Accounting, 8(18), 23-34.

Mokhtar, S. M., Sori, Z. M., Harnid, M. A., ... \& Muhamad, S. (2009). Corporate governance practices and firms performance: The Malaysian case. Journal of Money, Investment and Banking, 11, 45-59.

Noor, M. A. M. (201 1). The effect of implementation of Malaysia code of corporate goverance (MCCG) 2007 on corporate governance attributes and financial performance. Ph.D DPA Dissertation, University Utara Malaysia.

Obiyo, O. C., \& Lenee, L. T. (2011). Corporate governance and firm performance in Nigeria. IJEMR, 1(4), 1-1.

Oroud, S. Y, Islam, Md. A., \& Tunku, S. T. A. (2016). The Effect of Cash Flows and Accruals on The Market Values of Equity: Audit Quality as A Moderator. International Journal of Current Research, 8(03), 28900-28908.

Oroud, S. Y, Islam, Md. A., \& Tunku, S. T. A. (2017). The Effect of Cash Flows on the Share Price on Amman Stock Exchange. American Based Research Journal, 07, 22-28.

Pallant, J. F. (2011). SPSS survival manual: A step by step guide to data analysis using SPSS (4th ed.). Crows Nest, NSW: Allen \& Unwin.

Persaud, S., \& Mason, A. (2000). Finance and Audit Committees Can Play a Key Role Both in Detecting Fraud and in Preventing it Canadian Fundraiser. Retrieved from http://www.vancouver.volanteer.ca

Pratheepkanth, P., Hettihewa, S., \& Wright, C. S. (2016). Corporate governance and financial performance: The case of Australia and Sri Lanka. Corporate Governance, 7(1), 1-12.

Reddy, K., Locke, S., \& Scrimgeour, F. (20 10). The efficacy of principle-based corporate governance practices and firm financial performance: An empirical investigation. International Journal of Manc gerial Finance, 6(3), 190-219.

Rezaee, Z., Kingsley, O. O., \& Mimmier, G. (2003). Improving corporate governance: The role of audit committee disclosures. Managerial Auditing Journal, 18(6/7), 530-537. https://doi.org/10.1108/02686900310482669

Roberts, S. C., Little A. C., Gosling, L. M., ... \& Petrie, M. (2005). MHC-heterozygosity and human facial $\begin{array}{llll}\text { attractiveness. Evolzction } & \text { 213-226. }\end{array}$ https://doi.org/10.1016/j.evolhumbehav.2004.09.002

Sarbanes, P., \& Oxley, M. (2002). Sarbanes-Oxley Act of 2002 the Public Company Accounting Reform and Investor Protection Act Washington. D.C: U.S. Congress,.

Swamy, V. (2011). Corporate governance and firm performance in unlisted family owned firms. Working Papers Series, 4(2), 37-52.

Treadway, J. C., Jr. (1987). Report of the National Commission on Fraudulent Financial Reporting. Washington, D.C.

Wei, G. (2007). Ownership structure, corporate governance and company performance in China. Asia Pacific Business Review, 13(4), 519-545. https://doi.org/10.1080/13602380701300130

Zahra, S. A., \& Pearce, J. A. (1989). Boards of Directors and Corporate Financial Performance: A Review and Integrative Model. Journal of Management, 15(2), 291-334. https://doi.org/10.1177/014920638901500208

\section{Copyrights}

Copyright for this article is retained by the author(s), with first publication rights granted to the journal.

This is an open-access article distributed under the terms and conditions of the Creative Commons Attribution license (http://creativecommons.org/licenses/by/4.0/). 